Understanding the Daniels Case on s.91(24) Constitution Act 1867

\author{
Paul L.A. H. Chartrand \\ Indigenous Peoples Counsel (I.P.C.), BA., LL.B. (Hons). LL.M.
}

aboriginal policy studies Vol. 3, no. 3, 2014, pp. 115-131

This article can be found at:

http://ejournals.library.ualberta.ca/index.php/aps/article/view/22231

ISSN: $1923-3299$

Article DOI: http://dx.doi.org/10.5663/aps.v3i3.22231

aboriginal policy studies is an online, peer-reviewed and multidisciplinary journal that publishes original, scholarly, and policy-relevant research on issues relevant to Métis, non-status Indians and urban Aboriginal people in Canada. For more information, please contact us at apsjournal@ualberta.ca or visit our website at www.ualberta.ca/nativestudies/aps/.

UNIVERSITY OF ALBERTA

FACULTY OF NATIVE STUDIES
Aboriginal Affairs and 


\title{
Understanding the Daniels Case on s.91(24) Constitution Act 1867
}

\author{
Paul L.A. H. Chartrand \\ Indigenous Peoples Counsel (I.P.C.), BA., LL.B. (Hons). LL.M.
}

This is a commentary on the Daniels case released by the Federal Court of Canada on 8 January 2013. ${ }^{1}$ An appeal of the decision was heard in the Federal Court of Appeal in November 2013. It is expected that whatever decision is given in the latter court, the case will eventually go to the Supreme Court of Canada for a final decision.

The Daniels decision was the subject of intense and wide national coverage. Although a wide and vigorous reaction is something that Harry Daniels would have appreciated, it is regrettable that much of the coverage was based upon serious misunderstandings about what the case was about and what it meant. This commentary will try to explain briefly and clearly what the case was about. This commentary is intended for the general reader and not the legal professional. Accordingly, this commentary will be styled as much as possible in non-legal terms and in plain English. It will also be limited to the kind of broad overview that is possible for the purposes of the commentary and within its relatively short scope.

It must be disclosed that the writer was a personal friend of the late Harry Daniels, who died on 6 September 2004, and I am grateful to have been invited by Chris Andersen to write this commentary. I have many stories to tell, including one about the time I first met Harry at a national conference on Aboriginal Constitutional Reform at Queen's University in Kingston, Ontario around 1983 or 1984, but those stories are for another day and another forum. I should also disclose, however, that I had a minor role in the original drafting of the claims in the Daniels case. That happened at a memorable meeting in Edmonton with Harry and Professor Dale Gibson of the University of Alberta. I emphasize that this event was my only involvement with the case. It was later picked up by other able counsel and carried forward under the auspices of the Congress of Aboriginal Peoples, an organization of which Harry was the president when the action began in the early 1990s.

\section{What the Case Was NOT About}

As previously mentioned, the public media gave a lot of attention to the Daniels case, much of it misconceived. Generally, these reports described the case as deciding that NonStatus Indians and Métis people were to be "treated the same" as Status Indians, in the sense that they would be entitled to receive the benefits of social programs and services that are currently available to Indians who are so identified in the Indian Act and whose lives on Indian reserves are administered by the federal department of Aboriginal Affairs and Northern Development Canada. This false message generated all sorts of expressions

1 Daniels v. R. 2013 FC 6 (Federal Court) 08 January 2013, hereinafter Daniels. References in subsequent footnotes will be to the relevant paragraph number in this version of the written judgment.

aboriginal policy studies, vol. 3, no. 3, 2014

115

www.ualberta.ca/nativestudies/aps/

ISSN: 1923-3299 
of dismay over increased taxpayer moneys being allocated to more Indigenous people. The message hardly contributed to a fair reaction, and its reception often drew out the racist attitudes that many Canadians harbour against Aboriginal people. The comments made on the topic by readers in the comment sections of online newspapers are a rich source of evidence to support this point.

In light of this egregious failure by Canada's news media, it is worthwhile to quote the judgment on what the case was NOT about:

- "This is not a s.35 of the Constitution case nor the interpretation or application of any rights either under the Constitution or under specific agreements, nor is it about Aboriginal rights"; 2

-Furthermore, ${ }^{3}$ "The Plaintiffs are not claiming a right to specific legislation or access to specific programs";

-And "the Plaintiffs have not sought any order suggesting a duty to legislate or to have access to specific programs; they seek to know whether they fall within that class of people in respect of whom Canada [the federal Parliament] has the exclusive jurisdiction to make laws."

\section{Summary}

The Daniels decision in the Federal Court did not decide anything about Aboriginal rights, or about the entitlement of Métis and Non-Status Indian people to receive government services or other benefits.

\section{What the Case Was About}

\section{Who Brought the Case to Court?}

The plaintiffs; that is, the parties who brought the action; were individuals who identified themselves as Non-Status Indians and Métis persons, and the Congress of Aboriginal Peoples (CAP). The case was instigated by the late Harry W. Daniels, who was then president of CAP. The defendant was the government of Canada.

What Did the Plaintiffs Ask For?

Daniels was an action for a declaration. The declaration sought was that Métis and NonStatus Indians (MNSI) are Indians within the meaning of section 91(24) of the Constitution Act 1867, which grants the federal Parliament the exclusive authority to legislate in relation

2 Daniels, note 1, para. 19.

3 Daniels, para. 65.

4 Ibid, para. 72 . 
to all matters coming within the class of subject "Indians and Lands Reserved for the Indians." 5

The Daniels case is the first case in which a Canadian court has been asked to decide this question of Constitutional interpretation. The judge, Mr. Justice Phelan, granted this declaration, but did not grant two other declarations that were also sought. The two latter declarations are outside the scope of this commentary.

A declaration is a discretionary remedy, and does not legally compel any party to act. A declaration is useful in a political system where the government is expected to follow the law. The remedy in cases of failure of a government to abide by the law that is explained in a judicial declaration is the political remedy of exposure of the government's failure to abide by the rule of law and the possibility of influencing public opinion in elections. A declaration about the powers of a government cannot by itself compel an exercise of that authority to act.

The declaration in this case would serve the purpose of removing the federal government's ability to insist that it does not have the constitutional authority to legislate in respect to the subject-matter of MNSI. Successive federal and provincial governments have used the uncertainty about the 91(24) issue in Daniels to avoid the assertion by MNSI representatives that the federal government has the legislative authority to act and cannot, for that reason, avoid executive responsibility to act. That does not mean they will act. It certainly does NOT mean that the federal government will feel compelled to replicate the programs and services it provides to Status Indians for other constitutional Indians.

\section{Summary}

Daniels decided only that the MNSI are within the meaning of "Indians" in s.91(24) of Canada's Constitution and that, accordingly, Parliament has the authority to make laws in respect to MNSI, as it has done for Status Indians. The case does not compel Parliament or the executive government to do anything. Whether or not the government has any constitutional obligations to pass particular laws is a separate issue that was not dealt with in the case.

\section{The Case Is NOT about the Identity of Any Aboriginal People or "Nation"}

The Daniels case is about constitutional interpretation. It asks if Métis and Non-Status Indians are within the class of subject-matters in respect of which the federal parliament has exclusive authority (also called "jurisdiction") to make laws. The case is NOT about the identity of the Métis people as a distinct "people" or "nation," or about the identity of any Indian or First Nation people.

Section 91(24) assigns exclusive authority to Parliament to make laws respecting a group or category of people who are identified as "Indians." The Indian people who fall within the terms of the Indian Act (Status Indians) and the Inuit people in Canada are most

5 Daniels, para. 526. 
likely included. Daniels in the federal court decides that the Métis people and the Indian people who are not caught by the terms of the Indian Act are also included. The latter group has been known as "Non-Status Indians" for the reason that they do not have the legal status that is accorded by the Indian Act. The Indian Act does not purport to identify the members of an Indian people or nation: it deals with "Indian bands" that are created by the Act. Section 91(24) has been interpreted as creating a "racial classification." ${ }^{16}$ Obviously this classification is not a classification of Aboriginal peoples or nations.

\section{Summary and Conclusion}

Daniels is a decision about subject-matter jurisdiction or the scope of legislative authority to act. The case is not about the identity of the Métis people as a distinct "people" or "nation," or about the identity of any Indian or First Nation people.

Some commentators have suggested that the identity of the Métis Nation and those who belong to it ought to be an issue on appeal. The learned judge in Daniels observed that the evidence was less clear than for Non-Status Indians in the case of Métis people respecting their inclusion in 91(24). Arguments on s.35 identity on appeal may tend to increase the probability of a conclusion by appeal courts that the Métis are NOT included in s.91(24)

\section{Understanding the Constitutional Concept of "Jurisdiction over Subject-Matters"}

Canada is a federal system where legislative authority is divided between the federal and provincial governments. In Canada the generally accepted doctrine is that the total of all powers to make laws are held by the federal and provincial governments in accordance with the separation of legislative powers in the Constitution. The law of the Constitution allocates either exclusive or shared jurisdiction to the federal and provincial legislative bodies over particular subject-matters. For example, the federal government has exclusive power to make laws about the subject-matters of unemployment insurance, criminal law, banks, and the postal service, whereas the provincial legislatures have the exclusive authority over the subject-matters of municipal institutions, and property and civil rights in the province. Furthermore, the courts have recognized that laws of one order of government might affect a subject-matter that is within the jurisdiction of the other order of government to legislate provided that certain complex constitutional tests are met. The Daniels decision does not mean that the provinces will not have the power to make laws that affect the MNSI or their interests. Daniels means only that the federal Parliament has the exclusive authority to make laws of the kind that the courts will characterize as laws "in relation to MNSI." An example of such a law would be a law respecting the constitutional rights of the MNSI.

Mr Justice Phelan was faced with the task of construing the meaning of "Indian." Accordingly, he decided that, for the purposes of characterizing the scope of the term "Indian" in s.91(24), the MNSI are characterized by their "affinity for their Indian heritage

6 Daniels, para 530. 
without possessing Indian status."7 For the same purpose, based upon the evidence, "The single most distinguishing feature of either non-status Indians or Metis is that of "Indianness," not language, religion, or connection to European heritage."

Factors such as language or religion are appropriate indicators to identify ethnic communities or "nations," so the judge was right not to be misled into adopting them.

The "affinity for their Indian heritage" element accomplishes, perhaps inadvertently because the judge did not mention the point, the task of creating a category that excludes the French-Canadian people, who can claim the status of an Indigenous people, but whose affinity associates that people with their European heritage. The emergence of the FrenchCanadian people on North American soil will not be relevant to the development of the doctrine of "Aboriginal" rights.

The description of "Indian" persons and groups against which the exercise of legislative power under s.91(24) is to be tested includes not only members of rights-bearing communities but also groups and individual persons who may or may not be associated with such communities. ${ }^{9}$ Parliament's authority extends to both the mandate to respect and protect the rights that are affirmed and recognized in s.35 of the Constitution Act, 1982 and extends also to subject-matter that does not involve any collective rights. Parliament may make laws under s.91(24) that extend to persons who are not Status Indians but who are within the class of MNSI.

An example of a modern exercise of such federal legislative authority is the legislation that resulted in the addition of a substantial number of persons to the Indian Act register. ${ }^{10}$

An historical example of legislation that extends to MNSI persons as well as to "status Indians" is the 1884 amendment to the Indian Act which provided for a penalty in respect of "whoever induces, incites or stirs up any three or more Indians, non-treaty Indians, or halfbreeds (sic) apparently acting in concert," to make demands or requests to any government official "in a riotous, routous, disorderly or threatening manner ... etc." 11

Although, as has been earlier stated, the Daniels case is the first to ask whether MNSI are included within the subject-matter of s.91(24), it is useful to mention that there is judicial

7 Ibid, para. 117.

8 Ibid, para. 532.

9 Daniels, para. 546.

10 The reference is to the 1985 amendments to the Indian Act, known as Bill C31, and to the more recent amendments known as Bill C3. On December 15, 2010, Bill C-3: Gender Equity in Indian Registration Act received Royal Assent. This bill became law on 31 January 2011. The title of the bill is misleading: there is no such thing as "gender equity" in the constitutional law of Canada. The Charter of Rights contains a provision respecting "sex equality." It is speculated that the title was adopted for reasons of political expediency.

11 An Act further to amend The Indian Act, 1880, S.C. 1884, c.27, s.1. Another example is section 14(2) of the Indian Act, 1880, S.C. 1880, c.28, which confirmed the possession and right of residence of the "Halfbreeds who are by the father's side either wholly or partly of Indian blood now settled in the Seigniory of Caughnawaga." 
authority on the meaning of s.91(24). The SCC has described the scope of s.91(24) as "the core of Indianness," which has been explained as a reference to Indians and "what they do and what they are." These are references to the rights and status of Indians. It is important to appreciate that the term "Indian" in this context does not mean only "Status Indians" but all Indians who may belong to communities that have constitutional rights. Since the Métis people have Aboriginal rights protected by s.35, those rights are part of the core of s.91(24).

\section{Summary}

The Daniels decision in the federal court decides that Métis and Non-Status Indians people are included within the federal power in s.91(24) of the Constitution Act 1867 to make laws about the subject-matter of "Indians." Parliament has historically made laws that applied to both groups. The decision does not establish any constitutional tests to identify any "Aboriginal people" that is recognized in s.35 of the Constitution Act 1982. The case does not concern the matter of identifying any Indian or Métis "people" or "nation" or a constituent community that has constitutional or legal rights.

\section{The Vexed Concept of "Race"}

Section 91(24) assigns law-making power over a group or category of people and is unique among the powers in the Constitution Act 1867 for that reason. The matter of having a power to single out a group of people for special laws can obviously lead to very contentious debate. The power appears to be one that reflects the history of British colonization and its conception of humanity as being divided amongst different "races." Australia's Constitution, enacted in 1901, also has a "race" power about which a leading textbook states "The Constitution was adopted at an historical high-point for racism." (Hanks, Keyzer, and Clarke 1999, p 55, par. 2.1.4) Nevertheless, the judge in Daniels was, according to the rules applicable to judicial decision-making, bound by Supreme Court of Canada (SCC) jurisprudence to adopt the concept of "race" to interpret s.91(24). ${ }^{12}$

Some of the concepts of "race" that were held at the time when the Constitution Act $1867^{13}$ was enacted will probably strike contemporary readers as being rather bizarre. Here is an example of the way that one British newcomer viewed Métis and Indian people in western Canada in the nineteenth century:

My criterion for distinguishing a halfbreed from an Indian is not colour, hair or morals, for these all fail in pointing out your man at times. I take the nostrils. The pure Indian, whose blood has never been polluted by Europeans, has a large distended nostril, all of those who have any portion of European blood, have their nostrils contracted in proportion to their approximation to Europeans. ${ }^{14}$

12 Daniels, 151. The SCC case is Canard.

13 The Act was originally known as the British North America Act 1867 (BNA 1867). It was renamed by the Constitution Act 1982, a point of Constitutional terminology and law that has very often been overlooked in non-legal and some legal publications.

14 Foster $(1972,112-13)$, quoted in Chartrand $(2002,302)$. For an example of a racist description of the inherent features of the Métis people in St Laurent, the writer's home community, see Giraud (1937). 
The task of conceiving a defensible meaning for the term "race" in contemporary Canada is difficult. Among other reasons is that the Charter of Rights and Freedoms contains a prohibition against racial discrimination while it also permits affirmative action programmes for individuals or groups identified as a "race." It is important that the interpretation of the "race" concept for the purposes of 91(24) be defensible in this constitutional context. ${ }^{15}$

The judge in Daniels felt bound to adopt the racial category: ${ }^{16}$ "On the evidence in this case, both non-status Indians and Metis are connected to the racial classification Indian by way of marriage, filiation and most clearly intermarriage." In this view, the concept of "race" appears to bear a biological connotation, and the judge strives to introduce other factors with which to link the MNSI to this "racial category." By linking them, he absorbs them into the biological category.

Mr Justice Phelan quite clearly adopted the biological fallacy of "race" at various points in his written decision, including by stating in reference to a case in Labrador, that "In Labrador, as found by Justice Fowler in Labrador Metis v. Newfoundland ... there was a mixing of Europeans and Inuit along the coast resulting in the present day Labrador Metis." This statement is quite clearly unwarranted. In the appeal judgment of that case, the court stated "The ... judge erred in identifying the respondents as Metis, when the parties had made their submissions on the basis of Inuit rights ..." ${ }^{18}$ In the writer's opinion, the judge in the Labrador case did not actually decide that the applicants were Métis, but he would have been wrong if he had so decided.

The judge's discomfort with adoption of the biological category of "race" is evident in other places in the judgment, ${ }^{19}$ and he strives to avoid it when he includes MNSI within the subject of "Indians" by characterizing "Indianness" in the context of discriminatory policies:

Non-status Indians and Metis were differentiated from others in Canadian society, particularly Euro-Canadians, because of their connection to this racial classification. To the extent that they were discriminated against or subjected to different treatment, such as in schooling, liquor laws, land and payments (detailed earlier), it was based on their identification with or connection to Indian ancestry. The single most distinguishing feature of either non-status Indians or Metis is that of "Indianness," not language, religion or connection to European heritage. ${ }^{20}$

15 For a useful discussion of the subject outside the sphere of law, see Brown \& Schenk $(2002,231)$. For a debunking of the concept in respect to legal recognition of Aboriginal people, see De Plevitz and Croft, (2003).

16 Daniels, para. 531.

17 Daniels, para. 231.

18 Newfoundland and Labrador v. Labrador Metis Nation, 2007 NLCA 75 (CanLII), para 53.

19 See, e.g., Daniels, paras. 558 and 568, and esp. para. 119.

20 Daniels, para. 532. 
This judicial elaboration seems to link the concept of "race" to one that has contemporary legitimacy for constitutional purposes, and that accords with contemporary understandings of the meaning of "race." To illustrate, it has been recently argued that

The concept of race as a biologically distinctive category was developed by northern Europeans who for much of their histories had been largely isolated from contact with people who differed from them physically or culturally ... the basic tenet of racist thinking is that physical differences such as skin colour or nose shape are intrinsically and unalterably tied to meaningful differentials in basic intelligence or "civilisation"... no scientific support for this assumed linkage exists. ... Human populations singled out as "races" are simply groups with visible differences that Europeans ... have decided to emphasize as important in their social, economic and political relations [italics in original]. ${ }^{21}$

In this view, s.91(24) is a constitutional provision that singles out those who belong to the "Indian race" for particular legal and policy purposes in Canada. The concept of "race" is thereby stripped of its original biological implications and is asserted as a valid constitutional category. This meaning of "race," which does not even need the feature of "visible differences," may be applied to both s.91(24) and to s.15 of the Charter of Rights and Freedoms.

The constitutional validity of laws pertaining to "Indians" on this view will be tested by assessing them in light of the legitimate purposes of s.91(24). Accordingly, no legislation that offends contemporary standards of public morality or constitutional values would pass muster. They would be struck down, without the need to adopt the biological connotation of "race," for being outside the purposes of s.91(24).

\section{Summary}

Daniels provides an opportunity for the Supreme Court of Canada if and when it hears the case on appeal to walk itself out of darkness on the concept of "race."22 The court must jettison the original biological connotations of the term, which offend current constitutional values and international human rights standards, and replace it with a defensible content that is linked to the legitimate policy purposes of s.91(24).

\section{Errors and weaknesses in the judgment}

The law that pertains to the interests and rights of the Aboriginal peoples in Canada is at an immature stage of development for many reasons, particularly because of their

21 J. R. Feagin \& C.B. Feagin, quoted in Perea, Delgado, Harris, and Wildman (2000, 56-57). See also the debunking of the race concept in Montagu (1997).

22 The SCC has adopted the fallacy of race and categorized Métis people by using a concept that is appropriate for purposes of animal husbandry as recently as Alberta (Aboriginal Affairs and Northern Development) $v$. Cunningham, 2011 SCC 37, [2011] 2 SCR 670, at para 70: “... The history of the Métis is one of struggle for recognition of their unique identity as the mixed race descendants of Europeans and Indians.” 
historical and contemporary political, economic, and social marginalization. As a result many constitutional and legal issues are still open-ended questions. Furthermore, the interpretation of the status and rights of Aboriginal peoples often, as it does in the Daniels case, requires an inquiry into the facts of history, which are prone to contentious debate. It is therefore not surprising to find points for disagreement. The following comments deal with my objections to some of the approaches and findings of the judge in Daniels, and I end with a note about the indefensible approach of Canadian governments in litigation involving Aboriginal peoples, as illustrated by the litigation history of Daniels.

The Manitoba Act Métis lands settlement scheme is not part of the "scrip system"

The judge in Daniels commented on the conflicts between the expert witnesses on the interpretation of s.31, the Métis lands provision in the Manitoba Act 1870, which is the Constitution of the province of Manitoba. In his observations and conclusions, the judge seems to have confused the scrip system, which was implemented to serve the provisions of the Dominion Lands Acts with the gradual land settlement scheme in s.31. ${ }^{23}$ The nonlegal experts also appear to have misinterpreted the character of the Manitoba Métis lands scheme by failing to appreciate its character as a fast-track version of the Indian enfranchisement system that had been designed for Eastern Canada (Chartrand, 1988, 1991). Under the authority of the Manitoba Act, a total of 6,034 allotments of land were made under s.31, whereas only 993 issues of \$240 scrip were distributed. I have argued elsewhere that the scrip issue was constitutionally invalid (Chartrand 1991, 74, 140). The scrip system began with the work of the Street Commission in 1885, the first of the several scrip commissions that operated into the twentieth century to deal with the Aboriginal title of the Métis people in the NorthWest regions that became the Prairie provinces in 1905. It is unfortunate that much of the literature misconceives the history of Métis scrip. Probably the most reliable source is Métis Lands in Alberta: A Political History (Métis Association of Alberta et al. 1981).

\section{The Principle of Protection: A Fundamental Feature of the Aboriginal-Crown Relationship}

Justice Phelan rejected the argument that the protection of Indian interests was one of the purposes of s.91(24). ${ }^{24}$ His conclusion is contrary to all the evidence. It goes against the very nature of the constitutional relationship between the Crown and Aboriginal peoples. The principle of protection has been affirmed not only in the terms of the famous Royal Proclamation of October 1763, but in landmark cases on Imperial constitutional law and in the modern judicial development of the concept of the fiduciary relationship. The policy purpose of protection is evident throughout the early history of Crown-Indian relations in Western Canada (Tobias 1976).

23 Daniels at paras. 316, 406, 407, 411, 415, 417, 421, 536, and 585.

24 Ibid., para. 539. 
The principle was the central reason for assigning legislative authority in respect to Indian interests to the federal order of government in Canada in order to protect those interests from local governments (see Bartlett ch 3 at 24; Hogg at 616, text accompanying note 2.) In this regard s.91(24) continued a long-standing British Imperial policy.

The decision to reject the principle of protection is difficult to sustain in light of the evidence, and difficult to understand because its acceptance assists and does not hinder the path to the same positive decision that Justice Phelan reached by another route.

\section{Misconceived Notions about Aboriginal Identity}

In addition to his shifting conception of "race," noted earlier, Mr Justice Phelan opined that the "mode of life" factor was unworkable for the purposes of identifying Indian people. ${ }^{25}$ This view contradicts the evidence where millions of folks are identified by their adherence to a religious faith. The style of life factor is considered by D.E. Sanders in the context of an examination of the question of Indian status (Sanders 1972).

The judge commented, as an aside, ${ }^{26}$ that an Aboriginal person was required for constitutional purposes to identify as belonging to one Aboriginal people to the exclusion of the others, referring to the Cunningham case in the SCC. There is nothing in Cunningham that requires a lower court to so decide. ${ }^{27}$ The notion is contrary to common sense and common experience. Many people in Canada profess multiple identities, and it would probably be difficult to find a Maori in Aotearoa/New Zealand who did not personally associate himself with more than one iwi or clan.

Furthermore, and this particular comment is not about anything Mr Justice Phelan stated, s.35 of the Constitution Act 1982 does not provide an exhaustive list of Aboriginal peoples, but simply provides that the Indian, Métis, and Inuit people are included within the meaning of the generic term "aboriginal." It is a common error in the general literature to state that the Constitution defines three aboriginal peoples. ${ }^{28}$ Not only is there no definition: there is no exhaustive list. There is no solid principle to shore up the mistaken judicial view that distinct tests or laws ought to be developed for distinct Aboriginal peoples. ${ }^{29}$

\section{Conclusion}

The courts ofCanada, acting through lawyers and judges who are generally inexperienced about the life and experience and the interests of Aboriginal peoples, are neither competent nor legitimate tribunals to decide questions about the most fundamental concerns interests

25 Daniels, para. $445-52$.

26 Daniels, para. 592.

27 See Alberta (Aboriginal Affairs and Northern Development) v. Cunningham, 2011 SCC 37, [2011] 2 SCR 670 at para 85 , where counsel argues that the court ought to recognize complex multiple identities.

28 An exemplary treatment of the subject of Aboriginal identity is Schouls (2003).

29 The SCC has undertaken, without constitutional warrant, to develop such a doctrine: see $R v$ Powley [2003] 2 SCR 207. 
and rights of the Aboriginal peoples. ${ }^{30}$ Some of the difficulties in Daniels have been very briefly identified.

One option to deal with the problem is the creation of specialized tribunals, as recommended by Canada's federal Royal Commission on Aboriginal Peoples (RCAP 1996, 2: $590-612) .{ }^{31}$

Another option available to the courts, in order to avoid deciding questions on matters such as Aboriginal identity, which ought to be decided by the Aboriginal "peoples" themselves, is a new doctrine of "political questions." In the United States, the courts have developed the concept that certain matters are properly for the executive and not the judicial branch of government to decide. The courts refuse to answer such political questions because they are beyond the authority of the courts to decide.

It is indefensible that, in Canada, appointed judicial civil servants have arrogated to themselves the authority to decide questions about the identity and membership of Aboriginal peoples or "nations." A proper doctrine of political questions in Canada would result in the courts deferring certain decisions on Aboriginal issues to the peoples and their representatives, not to the executive branch of the governments in Canada. ${ }^{32}$

\section{Governments' Disregard for the Law and Attempts to Frustrate Access to Its Own Courts}

The Daniels case offers a startling commentary on the general lack of respect for the law, the ethics of litigation, and the rule of law by representatives of governments acting in their political and legal capacities in cases involving Aboriginal parties in Canada. It is beyond the scope of this commentary to describe the many instances of government misbehaviour, including the dismissal of government lawyers who bring attention to these sorts of problems, and remarks by government ministers and officials. ${ }^{33}$

30 A recent illustration of the SCC's misconceptions is the following statement in Cunningham, where the court not only adopted the fallacy of race but also misconstrued the effects of s.35 and erred by overlooking the fact that the Métis were recognized as a distinct rights-holding group in 1870 in s.31 of the Manitoba Act: "section 35 of the Constitution Act, 1982 entrenched existing Aboriginal and treaty rights and recognized three Aboriginal groups-Indians, Inuit, and Métis. For the first time [author's emphasis], the Métis were acknowledged as a distinct rights-holding group" (para. 13). For an examination of the unfair distinctions between the law relating to Aboriginal peoples and other groups in Canada, see Chartrand (2008, 41-49).

31 It must be disclosed that the writer was one of the commissioners appointed to the RCAP by the Prime Minister.

32 The concept of "political questions" in Canada, but not in the context of the assertion that is made in the text, is examined in Sossin (1999, 141-200).

33 In a stunning commentary at a conference in Toronto in November 1996, Stephane Dion, a federal Cabinet Minister in the Liberal government, verbally attacked Chief Gordon Peters by stating explicitly that he, Dion, rejected collective rights and "nation-to-nation" status for Aboriginal people. This stance came from a federal Minister who was legally bound to respect the law of the Constitution, and who was therefore bound to recognize and affirm the Treaty and Aboriginal collective rights of Aboriginal peoples in s.35 of the Constitution Act 1982. The substance of the discussion appears in Fletcher $(1999,114-15)$. See also aanationtalk (2013). 
The federal government, through its lawyers, fought every inch of the way and tried every procedural technique possible to frustrate the Daniels case over many years.

Mr Justice Phelan was moved to characterize the defendant's "attacks and attempts to frustrate this litigation" as "disingenuous." 34 In one of the several earlier cases where federal lawyers had tried to derail the Daniels case, they were reminded that "unreasonable difficulty ought not to be thrown in the way of procedures in which claimants, acting bona fide, bring questions of great importance to the courts in order to obtain declaratory relief." ${ }^{35}$

The tactics of the government lawyers reached a high point of the bizarre, or a low point of public accountability, when they refused to acknowledge that their own documents were in fact government documents. On this point, the judge was moved to state "Leslie [an expert called by the Plaintiffs and a former government employee] had to be called by the Plaintiffs because the Defendants would not admit that a significant number of government documents were in fact government documents. The Defendants' position was wholly untenable and just a further example of the extent to which the Defendants would proceed in attempts to frustrate this litigation." ${ }^{36}$

In the litigation limbo, few can go as low as a well-instructed government lawyer.

\section{Conclusion}

The tactics that are frequently used by governments in attacking attempts by Aboriginal people to seek justice in the courts are an indefensible and unconscionable waste of public resources and arguably an indication of moral bankruptcy.

The law of Canada has been developed without the participation of the Aboriginal peoples. In order to legitimize the constitutional order in Canada in accordance with contemporary standards of public morality and human rights, or, in other words, to change it from a de facto order to a de jure order, it is necessary to engage the participation and consent of Aboriginal peoples. (Chartrand 2009, 2011) Although I take the view in this commentary that the decision in Daniels is correct, the case nevertheless serves as an illustration of some of the features of Canada's constitutional and judicial systems that must change.

34 Daniels, para. 500.

35 Daniels v. Canada (Minister of Indian Affairs and Northern Development), 2002 FCT 295, [2002] 4 FC 550, para 54.

36 Daniels, para. 137. 


\section{The Daniels case on appeal to the Federal Court of Appeal}

On 17 April 2014, the Federal Court of Appeal gave its decision on the appeal of the Daniels case that had been filed by the federal government. ${ }^{37}$

The Court, comprised of three judges of appeal who were all in agreement, upheld the trial judge's conclusion that the Métis and non-status Indians are within s. 91(24).

The Court amended the declaration, however, to exclude non-status Indians, because their inclusion in s. 91(24), which was admitted by the federal lawyers, is so obvious that a declaration would serve no purpose: ${ }^{38}$

As for non-status Indians it was conceded by the appellants that non-status Indians are those to whom status could be granted by federal legislation, assuming the legislation did not exceed the limits of section 91(24). The definition as conceded by the appellants in oral argument necessarily includes non-status Indians within that head of power.

It is astounding that news coverage of the case continues to misrepresent its meaning. The Winnipeg Free Press went so far as to devote an entire editorial column bemoaning the results of the exclusion of non-status Indians, which exclusion of course exists only in the minds of the newspaper's editorial board. ${ }^{39}$

One of the most useful constitutional and philosophical contributions of the Daniels case on appeal must be its unerring resolve, unprecedented in any previous case known to the writer, to cleanse the Constitution of Canada of the odious concept of "race." In order to do this, the Court had to refuse to follow the racist approach of the Supreme Court of Canada. The concept of human beings, and Aboriginal people in particular, comprising biological "races" was articulated in the Canard case, which dealt with the meaning of s. 91(24). Since the Canard decision, the Court has never made it patently clear that it understands or supports a complete rejection of the concept of "race." 40

372014 FCA 101, 17 April 2014 CanLII [Daniels].

38 Daniels para. 75, and see para. 76 for elaboration of the explanation.

39 “Indians Who Aren't Indians," Winnipeg Free Press, April 22, 2014, http://www.winnipegfreepress.com/ opinion/editorials/indians-who-arent-indians-256126711.html. An example of a comment on Daniels at the trial level that completely misinterprets the case and is driven by blind and unarticulated ideological leanings is Tasha Kheiriddin, “The problems with the Daniels decision," National Post, January 10, 2013, http:// fullcomment.nationalpost.com/2013/01/10/tasha-kheiriddin-the-problems-with-the-daniels-decision/.

40 In Powley, the Court included a racist component to its purported definition of "Métis"; see Paul L.A.H. Chartrand, "Defining the 'Metis' of Canada: A principled approach to Crown-Aboriginal Relations', chapter 2 in Frederica Wilson and Melanie Mallet, ed. Metis-Crown Relations: Rights, Identify, Jurisdiction, and Governance (Toronto, Irwin Law Ltd. 2008) at $37 \mathrm{ff}$. Note that 'race' is a term in s.15 of the Charter to which a meaning must be attributed, but in that context the concept of 'race' should be to identify the deluded thoughts of racists that lead to adverse discrimination of the kind that s.15 aims to prohibit. 
In the words of the Court of Appeal:

Having concluded that the Judge meant Indian heritage to mean indigenousness or Aboriginal heritage, and considering the definition given by the Judge at paragraph 117 of his reasons, it follows that the Judge considered the Métis to be a group of native or Aboriginal people who maintain a strong affinity for their Aboriginal heritage or indigenousness without possessing Indian status. The Métis Aboriginal heritage or indigenousness is based upon self-identification and group recognition as Métis, not First Nations. It follows from this that the Judge recognized the Métis to be a distinct people.

As mentioned in my earlier comment on the trial-level decision, this approach performs the function, probably not contemplated by the Court, of distinguishing Métis people from French-Canadians, who are also indigenous to Canada but are not one of the Aboriginal peoples recognized in s.35 of the Constitution Act 1982. It may be emphasized that the description of the Métis people for the purposes of s. 91(24) is not to be viewed as a definition of Métis people for the purposes of s. 35. As the decision stated at paragraph 110:

That said, I am not satisfied that it is necessary to exhaustively or definitively define the term Métis in order to determine whether the Métis people fall within the scope of section 91(24). The Constitution does not define "Indian" and the Supreme Court did not define "Eskimos" when determining they were included in section 91(24) in Re Eskimo Reference.

At paragraph 96, the Court stated: "The Métis have their own language, culture, kinship connections and territory. It is these factors that make the Métis one of the Aboriginal peoples of Canada." None of this is correct. Métis people speak a variety of languages, including Cree and Ojibwe, French and English. A very small group speaks a language that linguists have labelled Michif for their own scholarly purposes. ${ }^{41}$ The concept of "culture" is so vague that anthropologists do not agree on its meaning, so that statement cannot be taken as having any intelligible content. ${ }^{42}$ Métis people where I come from in Manitoba have kinship connections and territories about which our oral histories provide accounts, but it would be far-fetched to say that we are part of one kinship group with all Métis people, particularly when new-found Métis identities have been springing up since the 1982 constitutional amendments. The approach in Daniels should help to convince the many new adherents to a Métis identity to try identifying as non-status Indians instead. It is a simpler approach for the people who have been, incredibly, deliberating on whether to identify as Métis or as Indian.

41 It is a well-known fact of which a judge is entitled to take judicial notice that the Métis people speak a variety of languages. Even a European linguist describes these languages in Peter Bakker, A Language of Our Own: The Genesis of Michif, the Mixed Cree-French Language of the Canadian Metis (New York: Oxford U Press, 1997), 72-77; he concludes at 77, "They speak a number of languages of which Michif is the most remarkable."

42 See Neil Vallance, “The Misuse of 'Culture' by the Supreme Court of Canada," in Diversity and Equality: The Changing Framework of Freedom in Canada, ed. Avigail Eisenberg (Vancouver: UBC Press, 2006), 97-113. 
A sad final commentary is that the Court here demonstrated its gross misunderstanding of some important points of law relating to Aboriginal people, including the statement that an Indian woman would lose status by marrying a non-Aboriginal man. The true legal result prior to 1985 was loss of status through marriage to anyone not a status Indian. Furthermore, the Court stated, incorrectly, that s. 35, which is in Part II of the Constitution Act 1982, is part of the Charter, which is in Part I of that Act.

Even as we find reason to approve judicial decisions on Aboriginal issues, we are too often driven to distraction by the failures of our appointed judges.

Niwāhkōmākanak (“All My Relations”) 


\section{Bibliography}

aanationtalk. 2013. The Campaign to Erode Aboriginal and Treaty Rights. 29 January and 1 February. Last accessed 22 January 2014. http://nationtalk.ca/story/the-campaignto-erode-aboriginal-and-treaty-rights/.

Bartlett, R.H. 1990. Indian Reserves and Aboriginal Lands in Canada: A Homeland. Saskatoon: University of Saskatchewan Native Law Centre.

Brown, J. and T. Schenk. 2002. "Metis, Mestizo and Mixed-Blood." In P.J. Deloria and N. Salisbury, ed. A Companion to American History. Malden, MA, and Oxford: Blackwell Publishers.

Canada. 1996. Royal Commission on Aboriginal Peoples. Vol. 2: Restructuring the Relationship. Ottawa: Minister of Supply and Services.

Chartrand, P.L. 1988. "The Obligation to Set Aside and Secure Lands for the "Half-Breed" Population Pursuant to Section 31 of the Manitoba Act 1870.” LLM thesis, College of Law, University of Saskatchewan.

Chartrand, P.L.A.H. 1991. Manitoba's Metis Settlement Scheme of 1870. Saskatoon: University of Saskatchewan Native Law Centre.

- - - ed. 2002. Who Are Canada's Aboriginal Peoples? Recognition, Definition, and Jurisdiction. Saskatoon, Purich Publishing Ltd.

- - - 2008. "Defining the "Metis" of Canada: A Principled Approach to CrownAboriginal Relations." In Metis-Crown Relations: Rights, Identify, Jurisdiction, and Governance, ed. F. Wilson and M. Mallet. Toronto, Irwin Law Ltd.

- - , IPC. 2009. "Reconciling Indigenous Peoples" Sovereignty and State Sovereignty." AIATSIS Research Discussion Paper No 26, September. Australia: AIATSIS. http:// www.aiatsis.gov.au/research/docs/dp/DP26.pdf.

- - - 2011. "Negotiating Constitutional Reconciliation, Recognition and Legitimacy in Canada." Waikato Law Review 19(2): 14-28.

De Plevitz, L. and L. Croft. 2003. "Aboriginality Under the Microscope: The Biological Descent Test in Australian Law." QUT Journal of Law and Justice 3(1): 104-20.

Foster, J.E. 1972. "Missionaries, Mixed Bloods and the Fur Trade," The Western Journal of Anthropology 3 (1): 94-125.

Fletcher, J., ed. 1999. Ideas in Action: Essays on Politics and Law in Honour of Peter Russell. Toronto: University of Toronto Press, 1999.

Giokas, J. and R.K. Groves. 2002. "Collective and Individual Recognition in Canada: The Indian Act Regime." In Who Are Canada's Aboriginal Peoples: Recognition, Definition and Jurisdiction, ed. P.L.A.H. Chartrand, ch. 2. Saskatoon: Purich Publishing Ltd.

Giraud, M. 1937. "A Note on the Half-Breed Problem in Manitoba." The Canadian Journal of Economics and Political Science 3: 541-49. http://dx.doi.org/10.2307/136570.

Grammond, S. 2008. "Disentangling 'Race' and Indigenous Status: The Role of Ethnicity." Queen's Law Journal 33: 487-518.

Hanks, P., P. Keyzer, and J. Clarke. 2004. Australian Constitutional Law: Materials and Commentary, 7th ed. Sydney: LexisNexis Butterworths. 
Hogg, P. W. 2009. Constitutional Law of Canada, student ed. Toronto: Thomson Carswell. Montagu, A. 1997. Man's Most Dangerous Myth: The Fallacy of Race, 6th ed. Walnut Creek: Altamira Press.

Perea, J.F., R.Delgado, A. P. Harris and S. M. Wildman, ed. 2000. Race and Races: Cases and Resources For a Diverse America. St. Paul, MN: West Group.

Sanders, D.E. 1972. "The Bill of Rights and Indian Status.” UBC Law Review 7 (1): 81-105.

Schouls, T. 2003. Shifting Boundaries: Aboriginal Identity, Pluralist Theory, and the Politics of Self-Government. Vancouver: UBC Press.

Sossin, L. 1999. Boundaries of Judicial Review: The Law of Justiciability in Canada. Toronto: Thomson Carswell.

Tobias, J.L. 1976. "Protection, Civilization, Assimilation: An Outline History of Canada's Indian Policy." Western Canadian Journal of Anthropology 6: 13-30. 